\title{
Democidal Thinking: Patterns in the Mindset Behind Organized Mass Killing
}

Gerard Saucier

University of Oregon

Laura Akers

Oregon Research Institute

Follow this and additional works at: https://digitalcommons.usf.edu/gsp

\section{Recommended Citation}

Saucier, Gerard and Akers, Laura (2018) "Democidal Thinking: Patterns in the Mindset Behind Organized Mass Killing," Genocide Studies and Prevention: An International Journal: Vol. 12: Iss. 1: 80-97.

DOI:

https://doi.org/10.5038/1911-9933.12.1.1546

Available at: https://digitalcommons.usf.edu/gsp/vol12/iss1/8

This Articles is brought to you for free and open access by the Open Access Journals at Digital Commons @ University of South Florida. It has been accepted for inclusion in Genocide Studies and Prevention: An International Journal by an authorized editor of Digital Commons @ University of South Florida. For more information, please contact digitalcommons@usf.edu. 


\section{Democidal Thinking: Patterns in the Mindset Behind Organized Mass Killing}

Acknowledgements

Thanks are due to Seraphine Shen-Miller, Ashleigh Landau, and Nina Greene for assistance with various aspects of this research. 


\section{Democidal Thinking: Patterns in the Mindset Behind Organized Mass Killing}

Gerard Saucier

University of Oregon

Eugene, Oregon, USA

Laura Akers

Oregon Research Institute

Eugene, Oregon, USA

In such a world of conflict, a world of victims and executioners, it is the job of thinking people, as Albert Camus suggested, not to be on the side of the executioners.

-Howard Zinn ${ }^{1}$

\section{Introduction and Background}

Sociopolitical violence is a tremendous social problem, given its capacity to spiral into outcomes of moral evil (i.e., intentional severe harm to others). The capacity for evil is compounded when the violent perpetrators have access to the resources of government or other forms of central authority. The $20^{\text {th }}$ century saw 167 to 188 million deaths by organized violence, nearly $5 \%$ of all deaths during the century. ${ }^{2}$ Any cause accounting for such a high rate of premature mortality deserves research attention.

Valentino wrote that "if we hope to anticipate mass killing, we must begin to think of it in the same way its perpetrators do." ${ }^{3}$ Pursuing this imperative, we aim here to answer the question, "what were they thinking?" Suedfeld underlines the value of studying historical instances of mass murder together, so as to "identify possible universal, or at least, shared, factors as well as unique ones" if we hope to "move from post hoc explanations toward an enhanced ability to predict and to intervene before the worst happens" ${ }^{\prime 4}$. Policy experts have increasing interest in identifying the "triggers and accelerators of genocide and atrocities." ${ }^{5}$ With knowledge of how democidalists think and tend to express themselves, one might create a preventive early warning system ${ }^{6}$ in which rhetoric in various sources would be monitored for the degree to which the democidal mindset has developed. Previous work provides useful indicators, but no comprehensive framework for this mass-killing mindset.

Here, using content analysis of texts from a relatively balanced set of 20 prominent cases of democide from around the world, we proceed from identification of specific high-frequency themes into a more parsimonious grouping of broader themes. In the themes, one finds a web of oversimplifying beliefs that all tend toward inculpating an out-group, prefatory to massive violations of that group's human rights. We will propose that the greater part of this belief-web will be detectable in the rhetoric associated with any perpetrator of democidal mass violence. This emergent model is not only unprecedentedly comprehensive but likely, after further refinement, to be useful for prediction.

${ }^{1}$ Howard Zinn, A People's History of the United States (New York: HarperCollins, 1999).

${ }^{2}$ Niall Ferguson, The War of the World: Twentieth-Century Conflict and the Descent of the West (New York: Penguin, 2006), xxxiv.

${ }^{3}$ Benjamin Valentino, Final Solutions: Mass Killing and Genocide in the $20^{\text {th }}$ Century (Ithaca: Cornell University Press, 2004), 243

${ }^{4}$ Peter Suedfeld, "Theories of the Holocaust: Trying to Explain the Unimaginable," in Ethnopolitical Warfare: Causes, Consequences, and Possible Solutions, ed. Daniel Chirot and Martin E.P. Seligman (Washington, DC: American Psychological Association, 2001), 67.

${ }^{5}$ James P. Finkel, "Atrocity Prevention at the Crossroads: Assessing the President's Atrocity Prevention Board After Two Years," Series of Occasional Papers no. 2, United States Holocaust Memorial Museum, Center on Genocide Prevention (September 2014).

${ }^{6}$ Gregory Stanton, "Early Warning," in Encyclopedia of Genocide and Crimes Against Humanity, ed. Dinah Shelton (Thomson-Gale, 2005), 271-273.

Gerard Saucier and Laura Akers, "Democidal Thinking: Patterns in the Mindset Behind Organized Mass Killing" Genocide Studies and Prevention 12, 1 (2018): 80-97. 02018 Genocide Studies and Prevention. 
Defining Democide Within a Spectrum of Sociopolitical Violence

Genocide has been defined as "the sustained, purposeful action by a perpetrator [usually the state] to physically destroy a collectivity directly (through mass or selective murders and calculable physical destruction) or through interdiction of the biological and social reproduction of group members." ${ }^{\prime 7}$ The concept of genocide is ambiguous in scope. Sometimes it is taken to include murderous suppression of political opposition and sometimes not (as in the 1948 United Nations Convention, based on Lemke's well-known compromise to resolve an impasse in the convention). Some have remedied this gap by conducting studies of genocide plus politicide. ${ }^{8}$

Here, we adopt Rummel's broader term (democide), to be clear that political suppression is not artificially excluded. By this definition, democide is "the murder of any person or people by a government, including genocide, politicide, or mass murder." ${ }^{\prime 9}$ In our view, Rummel's definition is too extensive in taking the murder by government of a single individual (e.g., an assassination) to be democide; it would be better to restrict the term to systematic killing of large numbers of noncombatant (civilian) individuals. This definition does not require the stated purpose of eliminating an entire group. Our slightly adjusted definition of democide ends up similar in scope to Valentino's preferred terminology referencing "mass killing;" ${ }^{10}$ a difference is that Valentino used 50,000 deaths as a minimum threshold, whereas to take better account of democide against smallscale societies (with, in fact, often fewer than 50,000 lives to lose) we employed a lower threshold.

Our focus is on a psychological 'mindset' account of sociopolitical violence. We use the term mindset in a way consistent with dictionary definitions, meaning a fixed mental attitude that affects how someone interprets or responds to situations. For purposes of this research, mindset is defined pragmatically as aspects of such thinking patterns that are observable, that is, accessible in rhetoric, in public communications or official statements. This contrasts with private cogitations (in diaries or letters), ascertainable by an observer only years after horrendous events have occurred. Although these private thoughts would fit as well within a conceptual definition of mindset, the relative inaccessibility of sources means far less utility for real-time prediction, so they are not included within the operational definition used here. Unless one assumes a massive capacity for hacking into documents in a perpetrator's private life, it is impractical for a prediction model to lean on them. Our interest is pre-diction, not post-diction. Observable mindset components are important for prediction purposes, since they may be detectable before appearance of any of the democide-trending behavior. The decade-earlier democide-promoting mindset in Hitler's Mein Kampf is a memorable example.

\section{Mindset Themes Detectable in Previous Literature}

Many accounts proposed for democide are non-psychological. These invoke potential explanations like difficult conditions of life, intergroup competition, or conditions created by particular forms of social stratification or uneven distribution of power. Especially useful sets of mainly-society-level predictors are provided by Fein, ${ }^{11}$ Harff, ${ }^{12}$ and Williams. ${ }^{13}$ Fein's predictors included situations associated with war, refugees, rebellions stimulated by mistreatment of ethnoclasses, independent states (rather than colonies), totalitarian regimes, and impunity stemming from passive reactions of patron or neighbor states. Harff stressed the importance of situations involving political upheaval, autocracy, autarky, prior genocide, and an ethnic minority as ruling elite. Williams' analysis suggest that, roughly, mass killing occurs when at least three of the following four features are

\footnotetext{
${ }^{7}$ Helen Fein, Genocide: A Sociological Perspective (London: Sage, 1993), 23-24. Prevention, 9 (2016), 137-153.

${ }^{9}$ R. J. Rummel, Death by Government (New Brunswick: Transaction, 1994), 31.

${ }^{10}$ Valentino, Final Solutions.

${ }^{11}$ Fein, Genocide, 23-24.

${ }^{12}$ Harff, No Lessons Learned from the Holocaust?

${ }^{13}$ Williams, More Lessons Learned from the Holocaust.
}

${ }^{8}$ Barbara Harff, “No Lessons Learned from the Holocaust? Assessing Risks of Genocide and Political Mass Murder since 1955," American Political Science Review, 97 (2003), 57-73; Timothy Williams, "More Lessons Learned from the Holocaust - Towards a Complexity-Embracing Approach to Why Genocide Occurs," Genocide Studies and 
present: autocracy, salience (controversiality) of the ethnic status of the ruling elite, war or political upheaval, and autarky or exclusionary ideology. Exclusionary ideology (also prominent for Harff) can be considered a psychological factor, and as such will reappear later in this report.

Our focus here is on psychological accounts, emphasizing the mindset represented in and encouraged by perpetrators. Because we observed the previous literature on perpetrator rhetoric in democide to be rather scattered and lacking in coherent testable models, we elected to utilize this literature for diverse points of comparison only after first generating an inductive model. This model developed here is based on a wider and more culturally unbiased sampling of perpetrator rhetoric associated with the global phenomenon of democide than has been previously examined.

However, to give an initial picture of some key points in the existing literature, Table 1 lists a variety of candidate democidal-mindset variables gleaned from previous relevant literatures. Notably, a few of the variables are packaged as an explicit sequence: Allport described five degrees of the acting-out of prejudice, and Stanton's work on the stages leading up to genocide led to a partly similar sequence. ${ }^{14}$ Assembling puzzle-pieces together, the review suggests that organizers and perpetrators of democide could often share particular features of ideology and worldview. These range from exclusionary racialism and beliefs in the suppression of minorities, to emphases on zero-sum group competition, to group identification emphasizing visions of collective purity and unity, and to a more paranoid focus on internal enemies and threatening foreigners. A general effect might be unifying one's group by making competition and strife between groups seem intense and ever-present.

\section{Democidal Mindset in 20 Diverse Cases}

The content analysis to which we now turn utilized an approach similar to that used by Saucier et al. to model militant-extremist thinking. ${ }^{15}$ Here a similar approach is employed to delineate the mindset of democidal perpetrators. The object was discovery rather more than testing or confirming previous conceptions, aiming to maximize the likelihood of identifying important new themes. It was therefore carried out as an independent content analysis, observing what falls most readily and obviously out of relevant texts. This is a variant form of a grounded-theory study, ${ }_{1}^{16}$ proceeding from an open coding to an axial coding of texts that emphasizes potential causal conditions. As with grounded-theory studies generally, the aim was to generate a theory (or model) rather than test an existing one.

An independent, inductive content-analysis approach is sensible because those groups and individuals who commit acts of sociopolitical violence often generate publicly available text setting forth their beliefs and perspectives, often accessible prior to the onset of violence. These texts allow content analysis to identify common themes and linguistic tropes found among those most likely to act upon these beliefs in a violent fashion. One might identify elements that may appear in the texts and compile these elements into an index that will enable an assessment of the potential for violence. As a generative start-point, we assume the utility ultimately of a prediction approach within a structural theory of the phenomenon at hand. Such a theory would hypothesize diverse predictors, and the greater the number and intensity of these predictors present, the more likely the violence. This research is a first step toward identifying a model of attitudinal predictors.

\section{Selection of Cases and Documents}

Democide is geographically widespread, with perpetrators of many different stripes ideologically. Taking account of this, we began by attempting to unconfound as much as feasible the phenomenon of democidal violence from any specific kind of ideology, movement, or culture, or broad

\footnotetext{
${ }^{14}$ Gordon W. Allport, The Nature of Prejudice (Reading, MA: Addison-Wesley, 1954); Gregory Stanton, "Could the Rwandan Genocide have been Prevented?" Journal of Genocide Research, 6 (2004), 211-228.

${ }^{15}$ Gerard Saucier et al., "Patterns of Thinking in Militant Extremism," Perspectives on Psychological Science, 4 (2009), 256-271.

${ }^{16}$ John W. Creswell, Qualitative Inquiry and Research Design: Choosing Among Five Traditions (Thousand Oaks: Sage, 1998).
} 
Table 1. Compendium of Relevant Candidate Variables from Previous Sources.

\begin{tabular}{|c|c|}
\hline Potential democidal-mindset variable & Source \\
\hline $\begin{array}{l}\text { Five degrees in acting out of prejudice: antilocution avoidance, } \\
\text { discrimination, physical attack, extermination }\end{array}$ & Allport (1954) \\
\hline $\begin{array}{l}\text { Unfolding action-stages in genocide: classification, symbolization, } \\
\text { dehumanization, organization, polarization, prevention, extermination, } \\
\text { denial }\end{array}$ & Stanton (2009) \\
\hline $\begin{array}{l}\text { In-group favoritism arising from social categorization into in-group and } \\
\text { out-group }\end{array}$ & $\begin{array}{l}\text { Sherif et al., (1961); Tajfel et al. } \\
\text { (1971) }\end{array}$ \\
\hline Perceived competition between in- and out-groups & Pratto \& Glasford (2008) \\
\hline Classification-focused speech emphasizing power and mistrust & Donohue (2011) \\
\hline Dehumanization & $\begin{array}{l}\text { Baum (2008); Hollows \& Fritzen } \\
\text { (2010); Leader Maynard \& Benesch } \\
\text { (2016) }\end{array}$ \\
\hline Moral exclusion & Opotow \& Weiss (2000) \\
\hline Hate & Winton (2011) \\
\hline Cultivation of grievances from the past & Staub (2001) \\
\hline Calls for revenge or retaliation & Baumeister (1997) \\
\hline Extreme factionalism & Goldstone et al. (2010) \\
\hline Asserted/believed legitimacy of violent actions & $\begin{array}{l}\text { Sabucedo, Blanco \& De la Corte } \\
(2003)\end{array}$ \\
\hline Moral disengagement (from e.g., sanitizing language) & Bandura (2002)\ \\
\hline 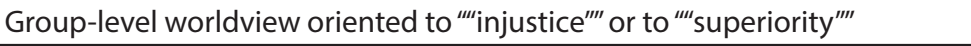 & Eidelson \& Eidelson (2003) \\
\hline Racism & Kiernan (2007) \\
\hline $\begin{array}{l}\text { Belief favoring suppression or exclusion of minorities; seeing "the people" } \\
\text { as one, indivisible, ethnic }\end{array}$ & Mann (2005) \\
\hline Ethnonationalism; emotional attachment to a group & McCauley (2001); Smith (2001) \\
\hline 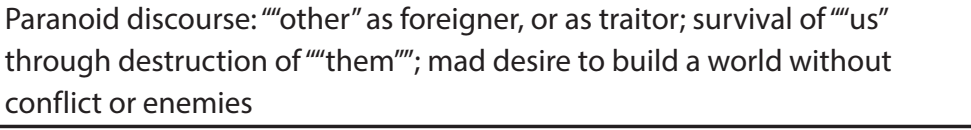 & Semelin (2007) \\
\hline Xenophobia & Brannigan (1998) \\
\hline Reactivity to blurring of traditional boundaries between groups & Green, Abelson \& Garnettt (1999) \\
\hline Ethnic purity concepts & Sémelin (2007) \\
\hline
\end{tabular}

geographical region. That is, we assumed that, until proven otherwise, democide is a pancultural phenomenon, not being endemic to a select group of nations or societies. Based on this assumption, in order to obtain a sufficient range of sources for making generalizations about the democidal mindset, one would need to examine materials arising from a diverse range of regions, religions, and political systems and orientations. Such a wide sampling would facilitate an eventual model that is, as much as might be prudent, culturally and politically neutral, and identify risk factors that apply across a wide range of contexts.

Without such heterogeneity, investigators might develop culturally biased models that do not generalize widely. Such models may unwittingly and erroneously incorporate aspects of thinking endemic to one region, religion, or political orientation. For example, if one studies only cases of African democide, political or cultural features associated with Africa may inadvertently and erroneously become part of a purportedly scientific model of democide. This would lead to erroneous overdiagnosis of African polities or societies as proto-democidal, and underdiagnosis 
elsewhere. Analogously, an analysis that focused only on democide carried out in communist regimes would lead similarly to a biased model, misconceiving aspects of communist systems as part and parcel of democidal tendencies. A different bias would arise if only fascist or authoritarian cases were examined. Although applied research might justifiably focus on democide with a particular provenance, a more general model of the phenomenon is needed.

Moreover, we sought an understanding not restricted to one subtype of democide. We included cases of several types, not limited to what is most commonly labeled as genocide. Included were programs of politicide or state terror in which a political opposition is eliminated, cases of colonialsettler violence, and cases of abusive economic exploitation of labor that resulted in mass deaths.

To ensure diversity of sampling, we divided the world into regions, seeking to identify at least one case from each region. In order to ensure there was sufficient contemporary relevance, we limited cases to the most recent 225 years (i.e., since the French Revolution). Each case had to fit the definition of democide, and to have had a record of actual violence involving the deaths in one or more target out-groups of at least thousands of people (a quantity quite large in scale when the group is small, as in many indigenous groups). To qualify, a case also had to have sufficient written documentary evidence (i.e., original statements) that would clearly indicate its mindset.

The cases we examined are listed and categorized in Table 2. The cases included six of the seven most deadly democides according to the figures of Rummel. ${ }^{17}$ The exception is the case of Chiang Kai-Shek (the Kuomintang case), which we omitted because it was estimated by Rummel to have fewer victims than the Maoist case (though still 10 million too many), and because we already had one case with Chinese perpetrators and did not wish our inductive model(s) to be biased by an overrepresentation of Chinese cases. We were not attempting an exhaustive study of three centuries of democide, but rather a sample sufficiently varied, along numerous axes, to reduce ethnocentric or regional bias.

The cases included seven on the Asian continent, four each in Europe and the Americas, three in Africa, and two in the islands south of Asia (i.e., 'Australasia'). There were four communist (or communism-aligned) cases, balanced by several (Argentina, Guatemala, Germany) that were overtly anti-communist. In nearly half the cases, perpetrators came from European-origin populations; in seven cases the perpetrators were Asian. The victims were more varied in their origin (five being European, seven Asian, three African; five were native peoples being victimized by settlers or colonizers). Such wide sampling is beneficial from a scientific standpoint: What a majority of the cases have in common cannot be characterized as specific to one kind of demographic or geographic context. Lest one develop a mistaken impression that the study is essentially of dictators or fascists, it should be noticed that several of the cases (USA, Australia, Bosnia) were in political contexts with some form of free elections, and some were mass political purges by Marxist regimes.

The groupings of cases in Table 2, though composed in an independent bottom-up manner, happen to correspond somewhat closely to the typology of Valentino. ${ }^{18}$ The top group corresponds with Valentino's dispossessive/ethnic type, the next group corresponds with his dispossessive/ communist type, although these cases have some features of a state-terrorist (coercive) type as well; these can be characterized also as ideological ${ }^{19}$ or reorganizing ${ }^{20}$ genocides. The third group resembles Valentino's dispossessive/territorial type, which Fein characterized as a "developmental" type of genocide. ${ }^{21}$ The fourth group fits Valentino's coercive/counter-guerrilla (and perhaps Harff's retributive) type, and the fifth group combines that type with the coercive/terrorist type. The last group fits partially with Valentino's imperial type, but might be more aptly characterized $\left(\right.$ after Dadrian $\left.{ }^{22}\right)$ as utilitarian genocide.

\footnotetext{
${ }^{17}$ Rummel, Death by Government.

${ }^{18}$ Valentino, Final Solutions.

${ }^{19}$ Harff, No lessons learned from the Holocaust?

${ }^{20}$ Daniel Feierstein, Genocide as Social Practice: Reorganizing Society under the Nazis and Argentina's Military Juntas (Douglas Andrew Town, Trans.). New Brunswick: Rutgers University Press, 2014.

${ }^{21}$ Fein, Genocide: A Sociological Perspective.

${ }^{22}$ Vahakn N. Dadrian, "Patterns of Twentieth-Century Genocides: The Armenian, Jewish, and Rwandan Cases," Journal of Genocide Research, 6 (2004), 487-522.
} 
Table 2. Listing and Categorization of Democidal Cases Examined in the Content Analysis.

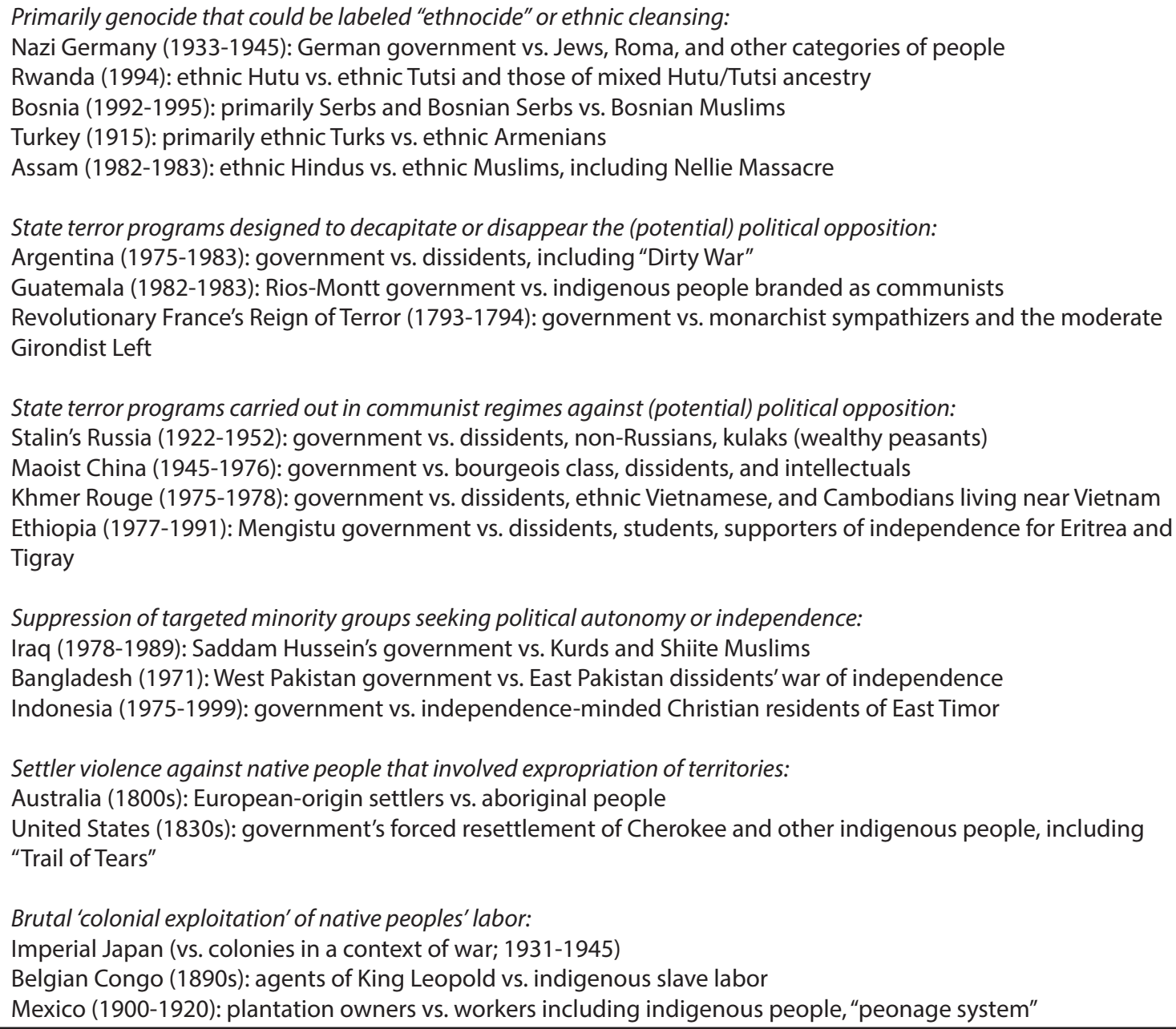

Having identified a diverse set of cases, we gathered documentary evidence for each case. Documentary evidence was drawn mainly from books (and sometimes other printed material such as pamphlets and periodical articles) and in a few cases from Internet websites. The great diversity of cases, while affording a globally representative perspective, produces challenges for creating strictly comparable corpuses of material for differing cases; one case might be richly documented in one kind of material, another not.

Whose statements should be in particular focus? Answering this question implies a view on who tends to be responsible for mass-killing events, and here we followed Valentino's argument, that a small group of leaders or elite are more responsible than ordinary people. ${ }^{23}$ We focused on documentation of statements from the highest level instigators and perpetrators relevant in each case, that is, the focus was not on the soldier or militiaman or mob member who carried out specific killings, but rather on the top of the chain-of-command that set the killings in motion. (This differentiates the present work from that leading to the construct of authoritarianism, which focused to a greater extent on attitudes among lay collaborators rather than elites, and that mainly in the single dramatic case of Nazism.)

${ }^{23}$ Valentino, Final solutions. 
Selection of materials was guided by a hierarchical scheme, attempting to draw material as much as possible from the highest levels of the hierarchy, resorting to lower levels of the hierarchy to the extent that higher levels could not be located in sources readily accessible via American academic libraries (in English, or French if not available in English, with much of the Chinese material [that not already translated] rendered into English by a bilingual research assistant). Texts written or spoken by democide-instigating leaders were the highest priority, followed by policy statements and texts from biographies of those leaders, followed by political histories more broadly about the time and place associated with the democide that referred to it, that included sufficient quotations from the leaders or policies.

The goal was to find indications of mindset - pattern of thinking - regarding deadly violence as related to achievement of sociopolitical power or other sociopolitical goals. We highlighted and extracted statements that stood out as directly revealing thinking and motivation, especially if in a dramatic and distinctive way. We sought statements that would indicate the characteristic thinking and motivation of each regime/group specifically as related to the democide, especially previous to or simultaneous with its occurrence. This general goal included (a) characteristic ways of using language or terminology that might reveal mindset, (b) views about what would justify elimination of people and other forms of violence, (c) views about enemies or opponents or out-groups, how to treat them, and what treatment they deserve, (d) views about the kind of higher authority that sanctions their (violent) actions or policies, (e) views about the proper role of government or other centers of authority within society, (f) views on what means are justifiable and allowable in achieving desired ends, and (g) whatever narratives, assumptions, beliefs, priorities (goals, motives, mission, value, perceived duties) that would help make sense of the aforementioned views. This was an open-ended search, with no axe to grind regarding which themes would emerge or which previous theories would be supported or not.

After the corpus of texts/statements consisting of broad sets of potentially relevant passages had been extracted by the second author, the first author examined the collected statements (which comprised 403 pages in a Word document, with 156,835 words including references and some annotations, made available as a supplement alongside publication of this article). The aim here was to identify key unifying themes, based partly on suggestions from the second author, and partly on acquaintance with the previous literature. But this was an inductive procedure, influenced but not constrained by previous work. A theme was taken to be present in statements from multiple sources when, in the first author's judgment, a reasonable person hearing the set of statements would recognize them to be making the same essential point. A first-stage goal was to identify specific rather than overly broad themes, which might lead to some categories in previous literature being initially broken into multiple subcomponents here, which may sometimes appear only subtly different; if one over-aggregates concepts at an early stage, much information that distinguishes concepts is lost from then on. We sought themes that emerged readily from the texts, rather than being limited to labels or framings for themes suggested in previous work by others. As a check on the plausibility of the themes originally induced from the observed data, two research assistants examining the collection of statements were able to identify instances of each of the themes in multiple, diverse cases. The more cases in which a theme appeared, the more prototypical of democidal mindset it was taken to be. ${ }^{24}$

\footnotetext{
${ }^{24}$ This assumes that the 20 cases should be weighted equally. One could argue that the differential severity of the cases should be taken into consideration, particularly severity indexed by the number of human lives lost (or estimated to be lost) in each case. It may be that some themes appear especially in the more severe cases, whereas others show the opposite pattern. To provide one index of severity, we used estimates, provided by Rummel's 1994 volume, of the total number of deaths involved in each (acknowledging that precise estimates are hard to establish). To examine whether distribution of any of these themes was confounded with severity of the case (number of million estimated to have died, capped at 3 million to eliminate positive skew) we calculated pointbiserial correlations between severity and presence versus absence of each of the themes. The allowed Type I error rate was defined by $99 \%$ confidence intervals, given the many correlations. With 20 cases, only large effects $(r>.50)$ will fall outside a 99\% confidence interval, and none did. The highest among the correlations were in the $.40 \mathrm{~s}$ (positive associations of dehumanization and racialism with severity), suggesting the possibility that, with a larger number of cases and thus higher statistical power, effects of severity might be found.
} 


\section{Convergent Themes}

We initially identified over 40 themes in at least five of the cases, but relied on a stricter threshold. Table 3 lists those 20 themes that occurred in at least half the cases, ordered by relative frequency of occurrence across all cases. A total of 10 themes were identified as central and primary, based on their occurrence in at least $2 / 3$ of the cases. That is, one finds each of these themes in a super-majority of cases; they are highly prototypical. These 10 themes appear in the top section of Table 3 . Table 3 indicates which themes were identified in each case. Notably, nine cases form a set for which all of the 10 primary themes were identified: These cases (Nazi Germany, Bosnia, Stalinist Russia, Maoist China, Imperial Japan, Khmer Rouge, Saddamist Iraq, Rwanda, and Bangladesh [East Pakistan]) might be regarded as the more prototypical illustrations of democidal mindset.

Ten secondary themes were identified in at least half of the cases. These themes appear in the bottom section of Table 3 .

A few of the Table 3 theme labels are truncations that benefit from a longer-form equivalent. "Uncivilized or uncivilizable" means that the target-group is held to be incapable of achieving any level of civilization. "Something held sacred" means that the sacredness of something is referenced as a rationale for a claim or for actions. "Attachment/entitlement to land" means that attachment to a particular territory is asserted or a group's entitlement to it is stated, as the group that can use it properly, or that has rights to it such that others taking it would be a moral violation (stealing).

\section{Do These Patterns Appear Even in Antithesis Cases?}

One possible objection is that the themes identified in the content analysis are widely characteristic of humans in general, or of leaders in general, or of crisis situations where subcultures are in conflict. If these were the case, the themes would appear even in texts generated by leaders who, in a serious conflict/crisis situation, did not resort to democide or even prevented democide from occurring. In order to guard against inclusion of themes that characterize movements or leaders generally (not just democidal ones), we made a similar examination of cases of leaders (or leading elites) governing in culturally/geographically diverse situations where a democide could well have occurred, but did not. These were not control cases so much as antithesis cases that bore promise of yielding the strongest contradicting evidence.

Identification of a suitable set of historical cases -- in which conditions were ripe for democide but none occurred, and where there was sufficient documentation, with the constraint that they be as diverse across culture and geography as our main 20 cases had been -- was very challenging. We did identify four instances strongly meeting these criteria. These geographically diverse cases included: Nelson Mandela and the ascension of the African National Congress to power in South Africa; Lech Walesa and colleagues in Poland after the fall of the Soviet-supported government there; Corazon Aquino's government in the aftermath of the Marcos regime; and handling of the loyalists after the American Revolution by George Washington and other patriot leaders. As with most of the 20 democide cases, these cases had an in-group with a strong sense of grievance toward an out-group, and the power to act on those grievances, because they had recently assumed greater power in government.

This was, simply put, a search for any contradictory evidence with respect to any of the themes identified in our main content analysis. We hoped that this step might enable a reduction in themes, allowing greater parsimony. Potentially relevant quotations - particularly, statements about other groups -- were extracted by procedures like those used for the democide cases, resulting in text-amounts falling in the same range as for our seven least heavily-documented democide cases (Mexico, Belgian Congo, Ethiopia, Assam, Guatemala, Bangladesh). The results of this work are detailed in a companion report dealing with possible preventative mindset with respect to democide (available upon request from authors).

Important to mention here is just a simple point: Extremely little in the way of democidalmindset themes in Table 3 was found in these cases; in their place we repeatedly found rhetorical restraint. While we did find some us-them dualistic rhetoric, it was not well connected to a good (us) vs. bad (them) distinction. We found evidence that George Washington (when he was a general, not a President) used dehumanizing language ("wolves") about the native American Iroquois, and suggested the desirability of their extermination during the Revolutionary War, when this tribe 
Table 3. Distribution of 20 Themes Detected in Statements from 20 Diverse Cases of Democide.
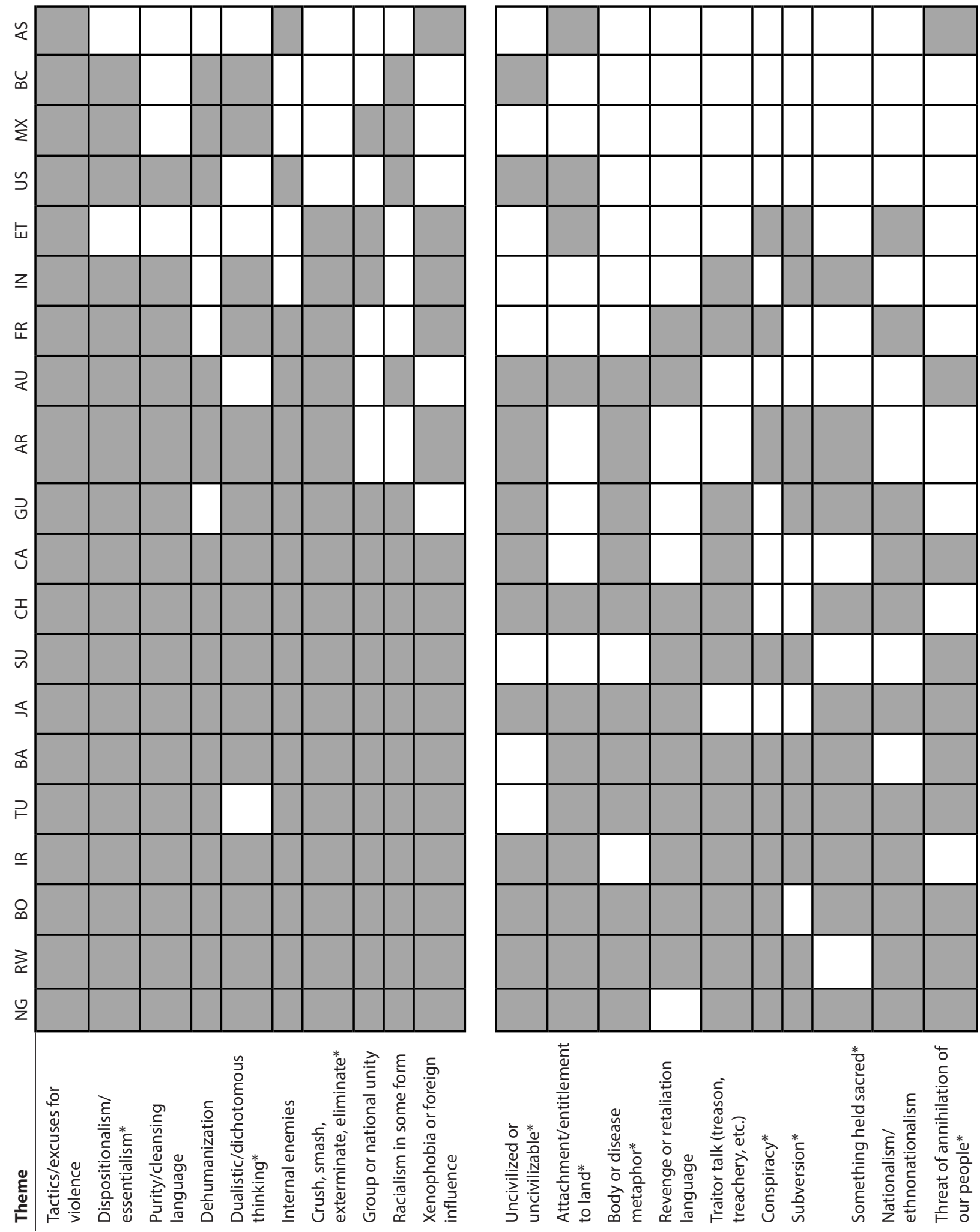

Note. NG - Nazi Germany, RW - Rwanda, BO - Bosnia, IR - Iraq (Saddam), TU - Turkey (Armenians), BA - Bangladesh, JA -

Japan, SU - Soviet Union (Stalin), CH - China (Maoist), CA - Cambodia, GU - Guatemala, AR - Argentina, AU - Australia (aborigines),

FR - France (Revolution), IN - Indonesia (E. Timor), ET - Ethiopia, US - United States (Trail of Tears), MX - Mexico (peonage), BC -

Belgian Congo, AS -Assam. * - Theme not readily found in Table 1. Shaded box indicates presence of a theme. 
sided with the British enemy; however his actual orders were only for the razing of villages and taking of prisoners. During that same war he labeled British loyalists as pests; but this labeling was not applied to the loyalists after the war when the potential for a score-settling democide was high. The other three cases involved leaders whose rhetoric was even more restrained than Washington's (and who were more likely to employ deliberate counter-measures to avoid mass violence).

Our conclusion is that leaders who promote peace and reconciliation demonstrate, if anything, a marked tendency to not engage in prototypical out-group-inculpating eliminationist rhetoric as represented by the 20 themes identified earlier. So the model shows promise of strongly differentiating such leaders from eventual perpetrators of democide.

\section{Potential Reductions and Expansions in the Inventory of Themes}

The 20 initial themes provide a useful first-pass model but a model with 20 indicators is not very parsimonious. Moreover, the 20 themes merely reflect those emerging in a bottom-up groundedtheory content analysis, and it is useful to consider what themes are found in the previous literature that might be added as supplements to this set of 20. This section considers both how the 20-theme model might be contracted to obtain more parsimony, or expanded to achieve potentially greater comprehensiveness.

Consideration of how the themes are conceptually related to one another suggests a few areas of thematic convergence. Several themes involve the moral-exclusionary evaluations of peoples: dehumanization, obviously, but also "uncivilized or uncivilizable," and likewise the "crush, smash, exterminate, eliminate" theme also tends to presuppose an evaluation of certain victims as having lives that do not matter, thus excluded from the universe of morally relevant targets (as in Fein's "exclusive universes of moral obligation" ${ }^{25}$ ). "Ethnic exclusionism," a psychological-attitude construct mentioned prominently in the previous literature (e.g., in work by Harff and Williams ${ }^{26}$ ), is conceptually related to moral exclusion, but also to themes (including racism) involving a reductive group-essentialism. These themes - racialism and dispositionalism/essentialism tend to assume an essence inhering in a group, held then to be highly determinative of the characteristics of those within that group. That is, the essential qualities of the group (which may very well be stereotypes) are the defining fact about the individual: Not just that you are an $X$, but you are nothing but an $X$ (where $X$ denotes the name of some group). Persons are more or less deindividuated, with a strong assumption of within-group (out-group) homogeneity. This kind of worldview sets a foundation for collective blame ${ }^{27}$, making an attributional assumption that events are caused by collectives (categories of persons) rather than by differentiated individuals. These thematic convergences resonate quite strongly with the previous literature (and a good deal of content in Table 1).

Several of the themes (conspiracy, subversion, internal enemies, traitor talk) appear to be sometimes subtle variations on a paranoid way of viewing the political situation, and this is less well-represented in the previous literature. Although Dadrian references themes of traitors and internal enemies ${ }^{28}$ the prime representation of this view there is in work of Sémelin. ${ }^{29}$ But some 50 years ago, the label "paranoid style" was introduced by a prominent political historian. For Hofstadter ${ }^{30}$ it was a way of believing that takes frequent political form, associated with overreaching theories of vast and sinister conspiracies that are about to undermine or destroy a whole way of life. Paranoid style included a preoccupation with power relations, exaggerated fantasies of superior forces and conspiracies in the external environment, and an angry and antagonistic relation to the world within which enemies and constant battles are fundamental.

\footnotetext{
${ }^{25}$ Helen Fein, "Accounting for Genocide After 1945: Theories and Some Findings," International Journal on Group Rights 1, no. 2 (1993), 79-106.

${ }^{26}$ Harff, No Lessons Learned from the Holocaust?; Williams, More Lessons Learned from the Holocaust.

${ }^{27}$ Brian Lickel et al., "Vicarious retribution: The Role of Collective Blame in Intergroup Aggression," Personality and Social Psychology Review, 10 (2006), 372-390.

${ }^{28}$ Dadrian, Patterns of Twentieth-Century Genocides.

${ }^{29}$ Jacques Sémelin, Purify and Destroy: The Political Uses of Massacre and Genocide (New York: Columbia University Press, 2007).

${ }^{30}$ Richard Hofstadter, "The Paranoid Style in American Politics," Harper's Magazine (November 1964).
} 
Another smaller convergence has to do with nationalism (importance of in-group unity, ethnonationalism), which is likewise only modestly prominent in previous democide-relevant literature. ${ }^{31}$ In the terms of Weitz, ${ }^{32}$ like essentialism involving race, this involves a way of classifying difference, here in terms of nation. Other themes from among the 20 show less conceptual convergence with one another, and many of these have little representation in the previous literature. But the previous literature does have references to a few of them: revenge-retaliation, ${ }^{33}$ xenophobia, ${ }^{34}$ and concepts of ethnic purity. ${ }^{35}$

These apparent convergences among the 20 themes are suggestive. Ultimately, however, thematic convergence would best be examined - and reduction to broader themes accomplished - in empirical data based on relative correlation among the themes as observed in descriptions of perpetrators or in self-indicated attitudes in the ordinary population.

There are some themes from the previous literature mentioned in Table 1 that did not emerge as themes detectable in text from a majority of our cases. These include hate, extreme factionalism, cultivation of grievances from the past, perceived competition between in- and out-groups, moral disengagement, and reactivity to blurring of traditional boundaries between groups. Expanding the assessment to include such themes would enable meaningful comparison between themes powerfully emerging from texts (the current 20) and expert conceptions, with respect to their prominence in further cases of democide, and their predictive capacity.

A close reading of classic works in genocide studies suggests a few additional promising candidate themes that may be useful for comparative assessment. These include placing national security above other goals, ${ }^{36}$ advocacy for removing restraints on state security agencies, ${ }^{37}$ believing that individuals must suffer for the good of the collective, ${ }^{38}$ and believing in or demanding change with high speed and scope and magnitude. ${ }^{39}$

We have mentioned numerous themes. Rather than having a single attitudinal cause, it appears that perpetration of democide is associated with a confluence of numerous differentiable attitudes. A complexity-embracing approach ${ }^{40}$ is needed for attitudinal as well as societal-level indicators. As a theoretical organization, these superthemes together move to define what Kaplan ${ }^{41}$ called a concatenated or factor theory, in which multiple concepts form a configural pattern converging on the focal concept, each playing some contributory role in accounting for it. Kaplan suggested that, although it provides less depth, this type of theory tends to be more broad, wide, and extensive than more deductive or hierarchical theories. We posit that the empirical evidence lends itself better to a factor theory - democidal behavior is difficult to reduce to a single explaining factor (such as hate or racism).

Could a single uniting conceptual framework, making sense of commonalities or interconnections among these broader themes, be found? Leader Maynard and Benesch ${ }^{42}$ detail an integrative model of dangerous speech and ideology focusing on what may be core constituents of democidal mindset (e.g., dehumanization and threat construction), but overall cite far fewer themes

\footnotetext{
${ }^{31}$ Fein, Accounting for Genocide After 1945.

${ }^{32}$ Eric D. Weitz, A Century of Genocide: Utopias of Race and Nation. (Princeton: Princeton University Press, 2003).

${ }^{33}$ Roy F. Baumeister, Evil: Inside Human Violence and Cruelty (New York: Henry Holt, 1997).

${ }^{34}$ Augustine Brannigan, "Criminology and the Holocaust: Xenophobia, Evolution, and Genocide," Crime and Delinquency, 44 (1998), 257-276.

${ }^{35}$ Sémelin, Purify and Destroy.

${ }^{36}$ Valentino, Final Solutions.

${ }^{37}$ Williams, More Lessons Learned from the Holocaust.

${ }^{38}$ Frank Chalk and Kurt Jonassohn, "Genocide: An Historical Overview," Social Education 55, no. 2 (1991), 92-96, 129.

${ }^{39}$ Valentino, Final Solutions.

${ }^{40}$ Williams, More Lessons Learned from the Holocaust.

${ }^{41}$ Abraham Kaplan, The Conduct of Inquiry: Methodology for Behavioral Science (San Francisco: Chandler, 1964).

${ }^{42}$ Jonathan Leader Maynard and Susan Benesch, "Dangerous Speech and Dangerous Ideology: An Integrated Model for Monitoring and Prevention," Genocide Studies and Prevention: An International Journal, 9, no. 3 (2016), 75-90.
} 
and evidence from fewer cases of democide than presented here. So one might expect vital insights to arise from whatever pattern emerges from our present empirical-data-based compendium of themes, beyond those offered by the model of Leader Maynard and Benesch.

Sémelin's $\mathrm{s}^{43}$ account of the basis for massacres is particularly salient given its frequent good match with themes we identified. Those who stand apart from one's 'people' are viewed suspiciously; in a "rage of oneness," with a "mad desire to build a world without conflict or enemies," ${ }^{44}$ there must be "unity at all costs against a common enemy." 45 With connotations of cleanliness and sacredness involved, there are the pure people and the impure people. One sees also a conspiratorial narrative, the internal enemy is the agent of the foreign external enemy, or the external enemy aids the internal one (e.g., Hitler's conflation of Jews with Russian bolshevism). One finds in either case a "delusional rationality", a "paranoiac type of discourse that unites 'us' through its evil-minded perception of 'them,"'"46 being "the survival of 'us' through the destruction of 'them."' 47

An unexpectedly wide variety of themes seem to characterize the thinking of democideperpetrators. But across this breadth of content, broad characterizations are possible. Generally they harmonize with Feierstein's impetus to identify "different discourses used to stigmatize otherness." ${ }^{48}$ An applicable generalization is this: All themes represent distortive oversimplifying beliefs that facilitate the inculpating of an out-group, and not just the out-group loosely or abstractly but with every member of that out-group thereby inculpated. That is, we see a group portrayed as threatening, impure, absolutely bad, and less than human, all in the context of a worldview that not only essentializes groups but treats group-membership as the essence of any individual. The unificatory vision of one's in-group only reinforces this pattern, partly by stimulating an agent to act on behalf of a group against a whole other group (as occurs in the phenomenon of vicarious retribution ${ }^{49}$ ). This interlocking of themes is common in the psychology of dictatorship - "a dangerous enemy... intends to attack and destroy us; we cannot afford to have dissent and disunity" 50 - has strong overlap with the overall pattern of democidal thinking.

The overall configuration of thinking enables large-scale violence against out-group individuals, by making it seem not only justified but necessary. That is, these themes converge to yield "eliminationism" - a derived belief that important problems will be solved by eliminating from society a particular group (cast as enemies of "our" people). One can discern in this fanatical eliminationism an overall cognitive tendency: to oversimplify, failing to tolerate uncertainty, nuance, exceptions to a rule, or alternative explanations. However, a better-informed overall characterization can be eventually discovered empirically, by determining which constructs or variables tend to correlate positively with all of the themes.

\section{Limitations and Future Directions}

Recent decades have seen important work identifying the political and societal concomitants of mass-killing events. ${ }^{51}$ The present work yields, as far as we know, the most comprehensive databased model currently available for understanding the attitudinal mindset behind mass killings. Essentially, it suggests a first, tentative psychological, attitudinal formula (or algorithm) for democide. A review of its limitations will help set the stage for enlarging the contribution in the future.

${ }^{43}$ Sémelin, Purify and Destroy.

${ }^{44}$ Ibid., 33.

${ }^{45}$ Ibid., 32.

${ }^{46}$ Ibid., 46.

${ }^{47}$ Ibid., 48.

${ }^{48}$ Feierstein, Genocide as Social Practice, 122.

${ }^{49}$ Lickel et al., Vicarious Retribution.

${ }^{50}$ Fathali M. Moghaddam, The Psychology of Dictatorship (Washington, DC: American Psychological Association, 2013).

${ }^{51}$ Fein, Genocide: A Sociological Perspective; Harff, No lessons learned from the Holocaust?; Williams, More Lessons Learned from the Holocaust. 
First, as implied in the preceding section, this model might be expanded into a broader framework by including additional candidate themes (i.e., variables) emphasized in previous literature though not making a salient emergence in our content analysis. A limitation is that although this model derives from one large empirical content analysis of a rather balanced set of cases of mass killing (most of them quite prominent), it may not have identified all relevant (and potentially predictive) kinds of content.

We relied as much as possible on explicit statements, to minimize guesswork about what kind of thinking characterized a case. As a result, we may have systematically underestimated how widely the identified themes are distributed: That is, perpetrators of democide might endorse a wider range of the statements of the nature presented here, even if they never thought to make them spontaneously and without prompting in a context that led to recording of the statement.

As Valentino emphasizes, democide (mass killing) is virtually always led by elites. ${ }^{52}$ But there are other classes of perpetrator, such as paramilitary bands not strictly within a government, and a general population that may look the other way or provide more overt support. ${ }^{53}$ Given our priority-hierarchy for selecting documents, the material in this content analysis was gleaned almost exclusively from the elites. But what of the two other levels, how would the framework here generalize to them? Does militia violence depends on the same factors? What role does the broader population play? Valentino points out that elites who perpetrate mass killing often recruit relatively sadistic individuals from the general population (sometimes from prisons) to carry out the killing, and also ideological fanatics; either sadists or fanatics may tend to exhibit many of the same attitudinal themes as the perpetrators. If the democidal mindset is more prevalent in a population (even if not among its elites), does that predict future democide? If the mindset is widely shared, and actually contributes to democide, it becomes a cultural factor; the prediction would be that such populations would see the emergence of more mass killings. Thus, constituents of democidal thinking have an important place in the measurement of political attitudes.

The content analysis sampled a large proportion of the most deadly democides of the past 225 years. In service of our goal of globally heterogeneous sampling of cases, we included cases that have not been cited as prototypical instances of genocide, such as state terror campaigns, forced removals of native peoples, and brutal economic-exploitation regimes. Table 3 demonstrates that these cases share many features with more prototypical instances, yet they may indeed be more peripheral instances, with fewer of characteristic themes of democidal thinking. Moreover, other major historical cases were omitted (e.g., the Kuomintang in China, the postwar partition of India, and the postwar expulsion of Germans from eastern Europe). Study of these omitted cases would be a validation test of the present framework, as would examination of more recent cases (e.g., Sudan, Syria, Myanmar).

The working model here represents only the early stage in development of a research paradigm. As is common for such an early stage, we rely heavily on a network of observations and inferences of a somewhat inductive nature. Because of the range of sources from which it was derived, the present inductive model has a content-validity basis. To examine to what degree predictive validity can be added to that initial basis, needed are further quantitative data: on the actual base-rate occurrence of the identified thinking patterns in everyday human activities, or in the rhetoric of political elites. Such patterns might be detected in attitudinal self-reports, or by eliciting norms about the thinking pattern (how appropriate it is for someone to think that particular way ${ }^{54}$ ). If any of the themes turn out to be fairly common, relying on them in isolation as constituent symptoms of a democidal mindset would yield a high false-positive rate, which would lead to a lower contribution to prediction.

\footnotetext{
${ }^{52}$ Valentino, Final Solutions.

${ }^{53}$ Michael Mann, The Dark Side of Democracy: Explaining Ethnic Cleansing (New York: Cambridge University Press, 2005).

${ }^{54}$ Christian S. Crandall, Amy Eshleman, and Laurie O’Brien, "Social Norms and the Expression and Suppression of Prejudice: The Struggle for Internalization," Journal of Personality and Social Psychology, 82 (2002), 359-378.
} 
For identifying concomitants and predictors, it matters very much which categories of sociopolitical violence one examines. ${ }^{55}$ Future research should seek to discriminate the democidal mindset from related but necessarily distinct phenomena. For example, some of the features we have identified -- a nationalist ideal, belief that intergroup (e.g., racial) conflict is inevitable, exclusion of what is foreign, preoccupation with revenge, all arising in a chaotic political/economic situation -- have also been proposed as contributors to the development of tyranny (i.e., the abuse of power ${ }^{56}$ ). Tyranny and democide will likely often overlap, but one is not a subset of the other. Although a majority of the cases in our content analysis did occur in the context of a national dictatorship, many did not fit this mold, being instead a kind of colonial economic-exploitation, or dominance of a region by an ethnic paramilitary, or suppression of minorities abetted by an elected government. It may be useful to understand democides without tyranny, in contrast to non-democidal tyrannies. Fein has categorized the varieties of life-integrity violations, genocide being but one type, in many ways the most severe; the other broad categories are slavery, and terror/torture.$^{57}$ While perpetrators of these practices may exhibit some of the democidal mindset found here, they may display important distinct elements. Further forms of sociopolitical violence deserving attention are war crimes, human sacrifice, and regimes of torture. More broadly, it may be useful to consider the extent to which this model captures key features of the mindset in extremely violent societies, where multiple population-groups may be victims and/or (along with organs of government) participants in massive physical violence.$^{58}$ Applications of this model to war itself are worth considering: Is it typical that war leaders and warriors themselves tend to gravitate toward thought-patterns partly like those of democidalists? There are indications that pro-war propaganda often involves dehumanization of an enemy, and framing attack as selfdefense (to prevent annihilation of 'us' by an enemy). ${ }^{59}$ Relations of democidal mindset to the thinking pattern of militant extremists ${ }^{60}$ might be revealing, since numerous democide perpetrators (e.g., Stalin, Hitler, Mao) began their political careers as extremists on the periphery of power; violent extremist-groups may violent governments make. Finally, Dadrian identifies two types of genocide that are rarely studied, and not addressed in the present research either: cultural genocide that aims at forced assimilation of subject peoples, and latent genocide where the mass killing is a fully unintended consequence. ${ }^{61}$ A question is whether these types of outcome involve the same observable perpetrator attitudes as other types of mass killing.

\section{Potential Applications to Democide Prevention}

We propose that perpetrators of democides - prior to the destructive actions - characteristically engage in thinking that includes a majority of the 20 themes we have identified. These are attitudes observable in text, potentially before the onset of mass killing. Further research is needed to confirm the predictive value of such mindset variables. Such elements can ultimately be tested as early-warning indicators of high risk for programs of mass killing, programs that might with appropriate intervention be averted if leaders or regimes are flagged at an early enough stage, before actual mass violence has been initiated.

The model we delineate is empirically based, consistent with much of the existing literature and (due to the globally diverse set of cases examined to derive it) not culture-bound. However, this framework has, as of yet, no demonstrated operationalization or means of assessment. So, an important issue that necessarily follows in this line of work is how to measure the relative degree of

\footnotetext{
${ }^{55}$ Frank W. Wayman and Atsushi Tago, "Explaining the Onset of Mass Killing 1949-87," Journal of Peace Research, 47 (2009), 3-13.

${ }^{56}$ Daniel Chirot, Modern Tyrants: The Power and Prevalence of Evil in Our Age (New York: Free Press, 1994).

${ }^{57}$ Helen Fein, Human Rights and Wrongs: Slavery, Terror, Genocide (Boulder: Paradigm, 2007).

${ }^{58}$ Christian Gerlach, Extremely Violent Societies: Mass Violence in the Twentieth Century (New York: Cambridge University Press, 2010).

${ }^{59}$ Stephan Lewandowsky et al., "Misinformation, Disinformation, and Violent Conflict: From Iraq and the 'War on Terror' to Future Threats to Peace." American Psychologist, 68 (2013), 487-501.

${ }^{60}$ Saucier et al., Patterns of Thinking.

${ }^{61}$ Dadrian, Patterns of Twentieth-Century Genocides.
} 
presence or absence of this mindset. An important application would be an assessment tool based on a broad-based understanding of the characteristics of this mindset. Such an index will allow researchers and workers in the field to gauge the degree to which the public speech acts (oral or written) of a group or individual reflect a democidal mindset. A reasonable starting assumption is consistent with a multiple-regression prediction approach: The more of these features are present, and the more intensely, the greater the probability of democide. And the more these features recede (a sign of effective intervention), the less that probability.

Among whom must these features be present? Any individual can exhibit this mindset, but those with the power to instigate democide must needs be in the government or the military, or otherwise be individuals with a following -- salient influencers of public opinion. Powerful and public figures all can be subjected to screening using this model as a filter.

As with the analysis that led to it, the core logic of such an index hinges on content validity. If it talks like a duck, there is a good chance it will walk like a duck, and in fact be a duck. Not to impugn waterfowl: For "duck" substitute "democide-perpetrator." An influential person whose rhetoric is redolent of that which Hitler, Stalin, Pol Pot, Saddam Hussein, and Robespierre used in common, is (by this rationale) more like to do what these characters did in common (democide). It is reasonable to propose that empirical evidence will back up this claim.

We argue that democidal episodes are rather like wildfires. They are rare but very powerful events. They do great damage and would best be prevented. And one can predict where they occur and where not, because they arise mainly in the context of identifiable risk factors: They are transmitted via individuals (most often leading elites) whose mindsets have a set of generalizable characteristics that, we argue, are crucial accelerators of democide. When individuals or groups move into a democidal mindset, potential for a devastating flare-up increases. To the extent that these individuals or groups cease to think in this manner, or the individuals who cultivate this way of thinking are hampered in their access to social power and group influence, risk factors are reduced and democidal events become less likely.

\section{Summary and Conclusion}

A content analysis of texts from 20 prominent cases of democide yielded an inductively observed pattern for democidal thinking including 20 themes present in at least half the cases. Characteristically in democide, under assumptions implying dualistic beliefs, members of an out-group are reduced to their group-categorization in an essentializing manner, excluded from moral consideration, identified with impurity or contamination and with violations of what deserves respect, and depicted as a dangerous and conspiratorial enemy, coupled with appeals to the desirable unity of the in-group. Each of these components is usually but not necessarily always present; it does appear that several of these broad themes will be regularly discernible in the eliminationist rhetoric associated with democide. Overall, themes represent oversimplifying beliefs that facilitate the inculpating of an out-group. And not just the out-group loosely or abstractly: Every member of that out-group is thereby inculpated.

The foregoing review and analysis is novel in diverse ways. It takes an unusually wide perspective, encompassing politicide and indigenocides in conjunction with well-known cases of genocide and ethnic cleansing, establishing moreover a relatively global and culture-neutral perspective that facilitates pancultural applications. It condenses the rich description afforded by 20 themes in democidal thinking into a more parsimonious organization of higher-order themes. And going beyond mere postmortem characterization of sociopolitical violence, it provides a start-point for multiple-indicator prediction of such based on observed attitudes evident in the perpetrators of mass-killing episodes.

\section{Acknowledgements}

Thanks are due to Seraphine Shen-Miller, Ashleigh Landau, and Nina Greene for assistance with various aspects of this research. 


\section{Bibliography}

Allport, Gordon W. The Nature of Prejudice. Reading, MA: Addison-Wesley, 1954.

Bandura, Albert. "Selective Moral Disengagement in the Exercise of Moral Agency." Journal of Moral Education, 31 (2002): 101-119. https://doi.org/10.1080/0305724022014322

Baum, Steven K. The Psychology of Genocide: Perpetrators, Bystanders and Rescuers. Cambridge, UK: Cambridge University Press, 2008. https://doi.org/10.1017/CBO9780511819278

Baumeister, Roy F. Evil: Inside Human Violence and Cruelty. New York: Henry Holt, 1997.

Brannigan, Augustine. "Criminology and the Holocaust: Xenophobia, Evolution, and Genocide." Crime and Delinquency, 44 (1998): 257-276. https://doi.org/10.1177/0011128798044002005

Chalk, Frank and Kurt Jonassohn. The History and Sociology of Genocide: Analyses and Case Studies. New Haven: Yale University Press, 1990.

-------. “Genocide: An Historical Overview.” Social Education, 55 no. 2 (1991): 92-96, 129.

Chirot, Daniel. Modern Tyrants: The Power and Prevalence of Evil In Our Age. New York: Free Press, 1994.

Crandall, Christian S., Amy Eshleman, and Laurie O'Brien. "Social Norms and the Expression and Suppression of Prejudice: The Struggle for Internalization." Journal of Personality and Social Psychology, 82 (2002): 359-378. https://doi.org/10.1037/0022-3514.82.3.359

Creswell, John W. Qualitative Inquiry and Research Design: Choosing Among Five Traditions. Thousand Oaks, CA: Sage, 1998.

Dadrian, Vahakn N. "Patterns of Twentieth-Century Genocides: The Armenian, Jewish, and Rwandan Cases." Journal of Genocide Research, 6 (2004): 487-522. https://doi.org/10.1080/1 $\underline{462352042000320583}$

Donohue, William A. "The identity trap: The Language of Genocide." Journal of Language and Social Psychology, 31 (2011): 13-29. https://doi.org/10.1177/0261927X11425033

Eidelson, Roy J. and Judy I. Eidelson. "Dangerous Ideas: Five Beliefs that Propel Groups Toward Conflict." American Psychologist, 58 (2003): 182-192. https://doi.org/10.1037/0003066X.58.3.182

Fein, Helen. "Accounting for Genocide After 1945: Theories and Some Findings." International Journal on Group Rights, 1, no. 2 (1993): 79-106. https://doi.org/10.1163/157181193X00013

--------. Genocide: A Sociological Perspective. London: Sage, 1993.

-------. Human Rights and Wrongs: Slavery, Terror, Genocide. Boulder: Paradigm, 2007.

Feierstein, Daniel. Genocide As Social Practice: Reorganizing Society Under the Nazis and Argentina's Military Juntas. Translated by Douglas Andrew Town. New Brunswick: Rutgers University Press, 2014. https://doi.org/10.26530/OAPEN 625248

Ferguson, Niall. The War of the World: Twentieth-Century Conflict and the Descent of the West. New York: Penguin, 2006.

Finkel, James P. "Atrocity Prevention at the Crossroads: Assessing the President's Atrocity Prevention Board After Two Years." Series of Occasional Papers no. 2, United States Holocaust Memorial Museum, Center on Genocide Prevention, September 2014.

Gerlach, Christian. Extremely Violent Societies: Mass Violence in the Twentieth Century. New York: Cambridge University Press, 2010. https://doi.org/10.1017/CBO9780511781254

Goldstone, Jack A., Robert H. Bates, David L. Epstein, Ted Robert Gurr, Michael B. Lustik, Monty G. Marshall, Jay Ulfelder, and Mark Woodward. "A Global Model for Forecasting Political Instability." American Journal of Political Science, 50, no. 1 (2010): 190-208. https://doi. org/10.1111/j.1540-5907.2009.00426.x

Green, Donald P., Robert P. Abelson, and Margaret Garnett. "The Distinctive Political Views of Hate-Crime Perpetrators and White Supremacists." In Cultural Divides: Understanding and Overcoming Group Conflict, edited by Deborah A. Prentice and Dale T. Miller, 429-464. New York: Sage, 1999.

Harff, Barbara. “No Lessons Learned from the Holocaust? Assessing Risks of Genocide and Political Mass Murder Since 1955." American Political Science Review, 97 (2003): 57-73. https://doi. org/10.1017/S0003055403000522

Harff, Barbara, and Ted Robert Gurr. "Victims of the State Genocides, Politicides, and Group Repression Since 1945." International Review of Victimology, 1 (1990): 1-19. 
Hofstadter, Richard. “The Paranoid Style in American Politics." Harper's Magazine, November 1964. Hollows, Kerrilee. and Katarina Fritzon. "“Ordinary Men' or 'Evil Monsters'? An Action Systems Model of Genocidal Actions and Characteristics of Perpetrators." Law and Human Behavior, 36, no. 5 (2012): 458-467. https://doi.org/10.1037/h0093987

Kaplan, Abraham. The Conduct of Inquiry: Methodology for Behavioral Science. San Francisco: Chandler, 1964.

Kiernan, Ben. Blood and Soil: A World History of Genocide and Extermination from Sparta to Darfur. New Haven: Yale University Press, 2007.

Leader Maynard, Jonathan and Susan Benesch. "Dangerous Speech and Dangerous Ideology: An Integrated Model for Monitoring and Prevention." Genocide Studies and Prevention: An International Journal, 9, no. 3 (2016): 75-90.

Lewandowsky, Stephan, Werner G.K. Stritzke, Alexandra M. Freund, Klaus Oberauer, and Joachim I. Krueger. "Misinformation, Disinformation, and Violent Conflict: From Iraq and the 'War on Terror' to Future Threats to Peace." American Psychologist, 68 (2013): 487-501. https://doi. org/10.1037/a0034515

Lickel, Brian, Norman Millerz, Douglas M. Stenstrom, Thomas Denson, and Toni F. Schmader. "Vicarious Retribution: The Role of Collective Blame in Intergroup Aggression." Personality and Social Psychology Review, 10 (2006):372-390.https://doi.org/10.1207/s15327957pspr1004 6

Mann, Michael. The Dark Side of Democracy: Explaining Ethnic Cleansing. New York: Cambridge University Press, 2005.

McCauley, Clark. "The Psychology of Group Identification and the Power of Ethnic Nationalism." In Ethnopolitical Warfare: Causes, Consequences, and Possible Solution, edited by Daniel Chirot and Martin E.P. Seligman, 343-362. Washington, DC: American Psychological Association, 2001. https://doi.org/10.1037/10396-021

Moghaddam, Fathali M. The Psychology of Dictatorship. Washington, DC: American Psychological Association, 2013. https://doi.org/10.1037/14138-000

Opotow, Susan and Leah Weiss. "Denial and Exclusion in Environmental Conflict." Journal of Social Issues, 56 (2000): 475-490. https://doi.org/10.1111/0022-4537.00179

Pratto, Felicia and Demis E. Glasford. "Ethnocentrism and the Value of a Human Life." Journal of Personality and Social Psychology, 95 (2008): 1411-1428. https://doi.org/10.1037/a0012636

Rummel, R.J. Death by Government. New Brunswick: Transaction, 1994.

Sabucedo, Jose Manuel, Amalio Blanco, and Luis De la Corte. "Beliefs Which Legitimize Political Violence Against the Innocent." Psicothema, 15 (2003): 550-555.

Saucier, Gerard, Laura Geuy Akers, Seraphine Shen-Miller, Lazar Stankov and Goran Knezevic. "Patterns of Thinking in Militant Extremism." Perspectives on Psychological Science, 4 (2009): 256-271. https://doi.org/10.1111/j.1745-6924.2009.01123.x

Sémelin, Jacques. Purify and Destroy: The Political Uses of Massacre and Genocide. Translated by Cynthia Schoch. New York: Columbia University Press, 2007.

Sherif, Muzafer, O. J. Harvey, O.J., B. Jack White, William R. Hood, and Carolyn W. Sherif. Intergroup Conflict and Cooperation: The Robbers Cave Experiment. Norman: University of Oklahoma Book Exchange, 1961.

Smith, Anthony D. Nationalism: Theory, Ideology, History. Cambridge, UK: Polity, 2001.

Stanton, Gregory. "Could the Rwandan Genocide have been Prevented?" Journal of Genocide Research, 6 (2004): 211-228. https://doi.org/10.1080/1462352042000225958

. "Early Warning." In Encyclopedia of Genocide and Crimes Against Humanity, edited by Dinah Shelton, 271-273. Farmington Hills: Thomson-Gale. 2005.

Staub, Ervin. "Ethnopolitical and other group violence: Origins and prevention." In Ethnopolitical Warfare: Causes, Consequences, and Possible Solutions, edited by Daniel Chirot and Martin E.P. Seligman, 289-304. Washington, DC: American Psychological Association. 2001.

. The Roots of Evil: The Origins of Genocide and Other Group Violence. New York: Cambridge University Press, 2007. https://doi.org/10.1037/10396-018

Sternberg, Robert J. and Karin Sternberg. The Nature of Hate. Cambridge, UK: Cambridge University Press, 2008. https://doi.org/10.1017/CBO9780511818707 
Suedfeld, Peter. "Theories of the Holocaust: Trying to Explain the Unimaginable," in Ethnopolitical Warfare: Causes, Consequences, and Possible Solutions, edited by Daniel Chirot and Martin E.P. Seligman, 51-70. Washington, DC: American Psychological Association, 2001.

Tajfel, Henri, M.G. Billig, R.F. Bundy, and Claude Flament. "Social Categorization and Intergroup Behavior." European Journal of Social Psychology, 1 (1971): 149-177. https://doi.org/10.1002/ ejsp.2420010202

Valentino, Benjamin. Final Solutions: Mass Killing and Genocide in the $20^{\text {th }}$ Century. Ithaca: Cornell University Press, 2004.

Wayman, Frank, and Atsushi Tago. "Explaining the Onset of Mass Killing 1949-87." Journal of Peace Research, 47 (2009): 3-13.

Weitz, Eric D. A Century of Genocide: Utopias of Race and Nation. Princeton: Princeton University Press, 2003.

White, Matthew. Atrocities: The 100 Deadliest Episodes in Human History. New York: Norton, 2012.

Williams, Timothy. "More Lessons Learned from the Holocaust-Towards a Complexity-Embracing Approach to why Genocide Occurs." Genocide Studies and Prevention: An International Journal, 9 (2016): 137-153. https://doi.org/10.5038/1911-9933.9.3.1306

Winton, Mark A. "Violentization Theory and Genocide." Homicide Studies, 15 (2011): 363-381. https://doi.org/10.1177/1088767911424538

Wood, Michael J., and Karen M. Douglas. "Online Communication as a Window to Conspiracist Worldviews." Frontiers in Psychology, 6 (2015): 836. https://doi.org/10.3389/fpsyg.2015.00836

Zinn, Howard. A People's History of the United States. New York: HarperCollins, 1999. 